\title{
Application of UAV remote sensing and GIS techniques for precision sampling in agricultural researches and practices
}

\author{
Norbert TÚRI - János KÖRÖSPARTI - György KEREZSI - Balázs KAJÁRI - \\ Csaba BOZÁN \\ National Agricultural Research and Innovation Centre (NAIK), Research Institute of Irrigation and Water \\ Management (ÖVKI), H-5540 Szarvas, Anna-liget u. 35., Hungary; E-mail: turi.norbert@ovki.naik.hu
}

Keywords: UAV, remote sensing, precision sampling, Digital Surface Model (DSM), sampling pattern

\section{Introduction}

Climate change and extreme weather conditions give challenge of maintaining crop yields in the agricultural sector. For the adaptation it is essential to continuously monitor our agricultural areas focused on soils and crops. Application of ordinary field investigation and sampling methods does not make possible to collect large amount of data from regional level. Data collection from a large area can be done by using remote sensing methods (Atzberger, 2013), or needs special sampling tools for e.g. Veris-3100 (specific soil electrical conductivity meter) developed for a precision approach (Balla et. al., 2017). Due to the modern solutions of remote sensing, heterogeneity can be determined by visual differences of the mapped area. To monitor these areas, sample patterns could be planned for precision survey. The shape of the sampling pattern and its repeatability are a very important point for tracking the conditions of the soil and crop on a specified spot. In agricultural research, and later in the practice, the field sampling strategy can evolve in many ways, depending on the properties of the area, and what previous measurement results are available (Milics and Balla, 2017).

\section{Materials and methods}

As a trial survey, a tile drained area was chosen near Mezőtúr in Békés County. Agricultural areas with functional tile drainage system have controlled water management condition, but unfortunately many of these systems are out of order in Hungary. To monitor the mentioned areas we need to know the location of the drain pipes during the whole year, but at present nor the pipe outlets, nor the surface differences unidentified. In a regular way, we could mark the line locations physically on the field, but because of the agricultural activity it is not possible in some cases (cultivation, crop rotation). In NAIK ÖVKI, a fix winged Trimble UX5-HP drone with Sony $\alpha 7 \mathrm{R}$ sensors (resolution: $36 \mathrm{MP}$; channels: Red, Green, Blue, NIR) was used for researches. For the trial survey our flight in Delair Aerial Imaging (DAI) Google Earth client software was planned, which was completed in August 2018. The post-processing of the aerial photographs had done with Trimble Busines Center (TBC) software. In TBC an orthophoto of the mapped area and a point cloud was generated which needed for creating DSM or DTM. Having the orthophoto makes a possibility to create the digital features (point, line, polygon) of the markable field objects in high accuracy applying ArcMap 10.4. software. Creation of features was the easiest way to plan the field sampling processes. The exported features in .kmz format were imported into the DAI, in which a trial project for soil compaction sampling with penetrometer was created. The flowchart of the mentioned methods and processes as shown in Figure 1. 


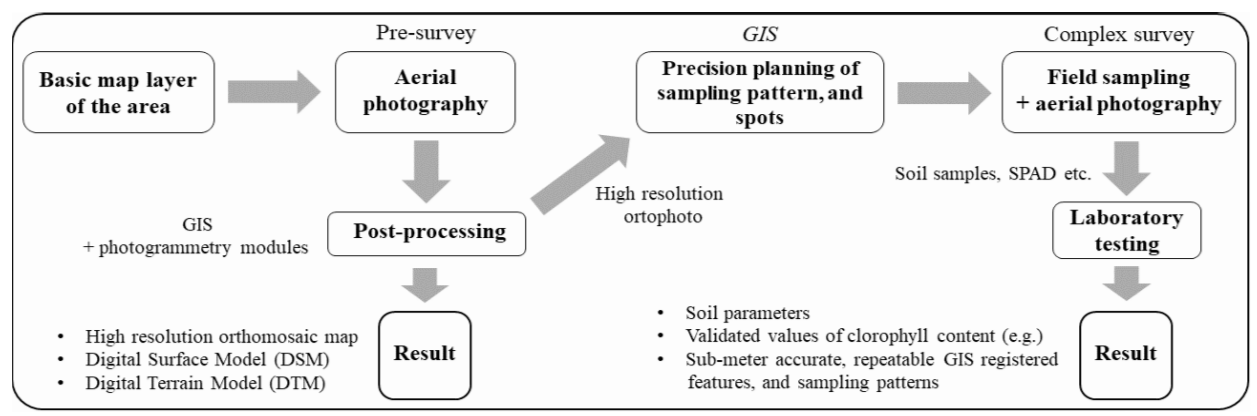

Figure 1. Flowchart of the precision sampling and survey methods. Source: own construction

\section{Results and discussion}

According to our result, Figure 2. shows all the survey outputs. Generated line features layer imported to the DAI software which was applied for sampling process of soil compaction over the pipelines and the intermediate areas. The introduced sampling process for the agricultural related survey could be applied in satisfying accuracy, so sampling could be repeated on our experiment any time of the year, but it depends on the weather and soil conditions as a limiting factor.

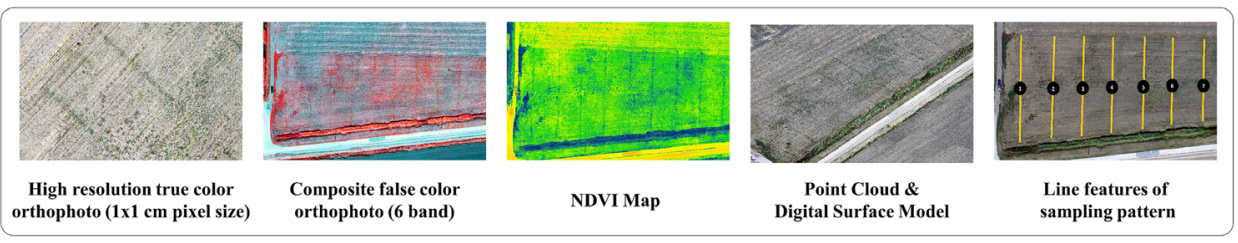

Figure 2. Output layers of the survey. Source: own construction

\section{Conclusions}

Using aerial survey and related GIS methods are essential parts of the precision sampling and monitoring. High resolution orthophotos are suitable to post-track any specified sampling point on the surface in high accuracy. Having the digital mark of the objects, the sampling and field experiments could be done in optional intervals during the vegetation period, or growing season.

\section{Acknowledgement}

Ministry of Agriculture founded our work (O14230 Development of agricultural water management - irrigation and excess water management, land use rationalization).

\section{References}

Atzberger C. (2013): Advances in Remote Sensing of Agriculture: Context Description, Existing Operational Monitoring Systems and Major Information Needs. Remote Sens. 2013, 5, 949-981; doi:10.3390/rs5020949

Balla I., Gyuricza Cs., Kovács G. P., Mikó P., Milics G. (2017): Precíziós talajnedvesség-meghatározás a talaj fajlagos elektromos vezetőképességének (ECa) mérésével. In: Milics G (szerk.) Precíziós gazdálkodás és agrárinformatika. Opal Média és Kommunikáció Bt., Budapest. pp. 100-101. (ISBN:978-963-12-8921-3)

Milics G., Balla I. (2017): Egyről a kettőre - Precíziós gazdálkodás gazdaszemmel II. rész: Mintavételek, adatok és a szaktanácsadás - Mi alapján, és hogyan döntsön a gazdálkodó? - In: Agro napló, ISSN 2061-5523,21: $5,35-36$. 